\title{
血清飢餓培養の実現を目指した，ハイブリドーマ細胞への細胞死耐性能の付与 ${ }^{\dagger}$
}

\author{
寺田 聡 $^{1+\dagger} \cdot$ 伊藤世人 ${ }^{1} \cdot$ 鈴木栄二 $^{2}$
}

\begin{abstract}
${ }^{1}$ 東京大学大学院工学系研究科 化学生命工学専攻, 113 文京区本郷 7-3-1
${ }^{2}$ (財) 地球環境産業技術研究機構 環境触媒研究室， 619-02 京都府相楽郡木津町木津川台 9-2

ハイブリドーマ細胞の血清飢餓培養には抗体生産能の上昇などの利点があるが, 急速な細胞死（アポト ーシス) を生じ, 実用的でない。こで細胞にアポトーシス抑制遺伝子 bcl-2 を導入し, 更に血清飢餓で スクリーニングして血清飢餓耐性株を樹立した。この株はスクリーニング前の 1.4 倍の Bcl-2 蛋白を発現 し, 野性株が 2 日で死滅する $0.2 \%$ 血清培地中で 4 日の培養が可能で, 通常の培養の 3 倍の比抗体生産速 度を示した。
\end{abstract}

\begin{abstract}
緒言
モノクローナル抗体，エリスロポエチン等の診断薬及び医薬品 として用いられる有用タンパク質の多くが動物細胞培盖により生 産されている。動物細胞培養は, 培地に高い純度が求められその うえ培地中に血清の添加を行わねばならない場合が多いこと, 動 物細胞の増殖速度が大腸菌などの微生物に比べて著しく遅いこと などのため，多大な費用を要する.

細胞培養による有用タンパク質の生産性は生細胞密度と細胞あ たりタンパク生産速度の積として表される．生細胞密度を高める 方法として, 筆者らはアポトーシス抑制遺伝子を動物細胞に導入 し，細胞死に耐性を付与することで達成し（Itoh et al., 1995)， また多くの研究者により例えば培地中の $\mathrm{pH}$ の調整法と増殖速度 の相関を検討したり（Shirai et al., 1994)，ホローファイバーを 用いた培養器を用いたり (Ogawa et al., 1992) することで高密 度連続培養の技術が開発されてきた。細胞あたり有用タンパク生 産速度を高める方法としては，筆者らが前報で報告したサイトカ インを用いる方法 (Terada et al., 1993) の他に，細胞周期の制 御，すなわち $\mathrm{G}_{1}$ 期に抗体生産速度が高い（Garatun-Tjeldst $\phi$ et al. 1976)ことを利用する方法, 培地中の乳酸濃度・グルコース濃 度を制御する方法 (Omasa et al., 1992) などが報告されている. また, $\mathrm{CHO}$ 細胞の場合, 細胞の形態変化と, 有用組換えタンパク の生産性に相関があるという興味深い報告もある (Yamamoto et al., 1997). 著者らは別の前報で細胞の死滅を防ぎながら増殖を抑 制し，かつ細胞あたりタンパク生産速度を向上させる方法として カフェインの培地中への添加や, グルタミン制限等を報告した (Suzuki et al., 1993).この時, 培地中の増殖因子の低減も細胞 あたりタンパク生産速度の向上には有効であったが, 培養 2 日以 内で細胞の死滅が始まり, 生細胞密度が著しく低下し, 結局培養 あたりの有用タンパク生産には寄与しなかった。

本報告では培地中の血清濃度を大幅に低減した培養の実現を目 指した。低血清培養が実現した場合, 次の利点が考えられる。ま ず，培地中でもっとも高価な血清濃度を低減する事で培養コス卜 を抑える効果があり，さらに有用タンパク質の精製段階で除去さ れるべき血清由来のタンパク質が少なく，この点からも費用低減
\end{abstract}

† 1997 年 7 月 31 日受理：化学工学会第 62 年会 (小金井, 1997 年 3 月) に て発表

†† tera@ bio.t. u-tokyo. ac. jp
に有効である。さらに血清中に含まれる増殖因子の欠乏は細胞増 殖の停止をもたらし, 細胞周期中の $\mathrm{G}_{1}$ 期に細胞が多く集まる. $\mathrm{G}_{1}$ 期はハイブリドーマ細胞においては抗体生産が他の期の 5 倍程度 高い（Garatun-Tjeldst $\phi$ et al., 1976）と言われるフェーズであ ク，これにより細胞あたりタンパク生産速度を高めることが期待 される.この点で, 正常な細胞増殖を意図した血清代替成分を含 む無血清培地（Murakami et al., 1984）を用いた無血清培養と本 研究の血清飢餓培養とが異なっている，培地中の血清濃度を著し く低減した場合, 速やかな細胞死が生じ, 著者らの経験によれば このような効果を十分得ることができなかった。そこで，培地中 の血清濃度を著しく低減した時生じる細胞死を抑制することが本 研究の目的である.

この目的を達成するために, 我々は細胞にアポトーシス抑制遺 伝子 $b c l-2$ を導入し, 細胞死に対する耐性の付与を目指した。 こ の研究成果は化学工学シンポジウムシリーズ (Terada et al., 1996）に報告した。本研究では, さらに一層, アポトーシス耐性 を強化することを狙った，まず，この $b c l-2$ 導入細胞をクローニ ングし，その中から血清飢餓に耐性を示すクローンを得ようと試 みた. しかし，この方法で得た細胞死に強い耐性を示す株は培養 末期に抗体生産が停止し, 抗体生産量も野性株に劣っていた（化 学工学会第 29 秋季大会にて発表).そこで本研究では次の戦略を 立てた. すなわち, $b c l-2$ 導入細胞を血清飢餓状態でほとんど死滅 するまで培養し，そのとき生き残った細胞を回収することで血清 飢餓による細胞死により強い耐性を持つ株の樹立を目指した。

\section{1. 実験方法と材料}

細胞 TNPハプテンを認識するモノクローナル抗体 $\mathrm{IgG}_{1}$ を産生するマウスハイブリドーマ細胞 $2 \mathrm{E} 3$ 株 (Mikami et al., 1991）を用いた。

培養方法と細胞密度の測定＼cjkstart細胞は $5 \% \mathrm{CO}_{2}$ インキュベー タ一内で湿度 $95 \%$ 以上, 温度 $37^{\circ} \mathrm{C}$ の条件で培養した。継代培養 は，10\%の牛胎仔血清を基礎培地 DMEM に添加して行った. 血 清を大幅に低減した血清飢餓培養は $0.2 \%$ の牛胎仔血清を基礎培 地 DMEM に添加して行った.

細胞数の測定には, 血球算定盤を用い, トリパンブルーで染色 されない細胞を生細胞，染色されるものを死細胞としてそれぞれ 計数した.

遺伝子導入 ネオマイシン耐性遺伝子を持つべクター BCMGSneo（Karasuyama et al., 1988）のサイトメガロウィル 


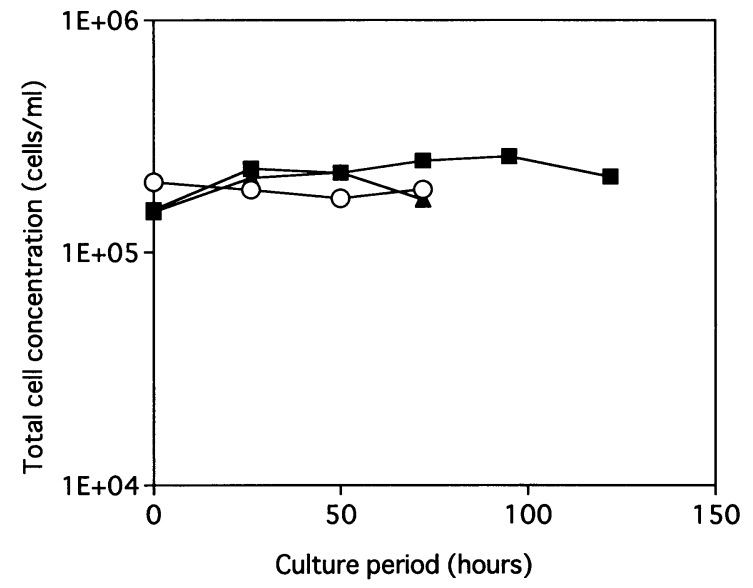

(a)

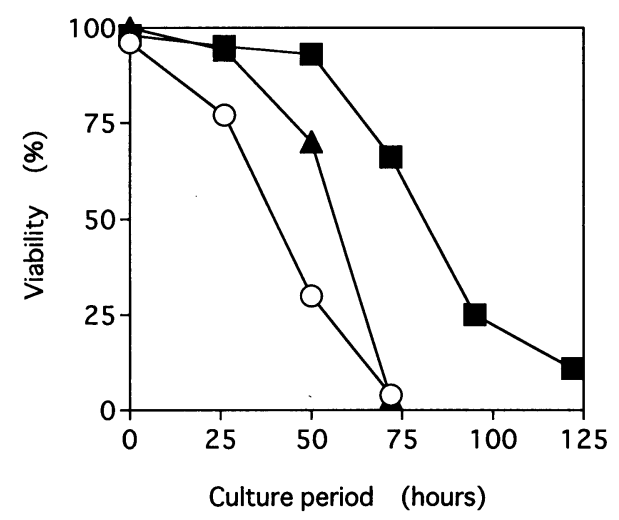

( b )

The cells were cultured in DMEM supplemented with $0.2 \% \mathrm{FBS}$ using 24 well-plate. Wild type (○), 2 E 3-bcl 2 (A), 2 E 3-bcl 2 -LS (

Fig. 1 (a) The growth curve, and (b) cell viability, of the hybridoma cells in serum starvation culture

スプロモーターの下流にヒト $b c l-2$ 遺伝子 (Tsujimoto et al., 1989）を挿入し BCMG-bcl 2 を構築した. $2 \mathrm{E} 3$ 細胞に BCMG$b c l 2$ を電気穿孔法で導入した後，抗生物質ネオマイシンの誘導 体 G 418 に対する薬剤耐性により発現細胞を選択した。得られた $b c l-2$ 発現細胞を $2 \mathrm{E} \mathrm{3-bcl} 2$ と命名した (Itoh et al., 1995). ま た, モックトランスフェクタントとして, $2 \mathrm{E} 3$ 細胞に BCMGSneo を導入した. 本研究ではこのモックトランスフェク タント（2E 3-BCMGSneo）を野性株として用いた。

血清飢餓耐性株の樹立 通常 $10 \%$ の牛胎仔血清を含んだ $\mathrm{DMEM}$ 培地で培養している $2 \mathrm{E} \mathrm{3-bcl} 2$ を，遠沈管に集め， $4{ }^{\circ} \mathrm{C}$, $1,000 \mathrm{rpm}$ で 5 分間遠心した後, 上清を除去した. 血清を全く含ま ない培地に懸濁した後, 同じ条件で遠心し, 再び血清不含培地に 懸濁して再度遠心した.上清を十分に除去した後, $0.2 \%$ の牛胎仔 血清を含んだ DMEM 培地に懸濁し，そのまま細胞の大半が死滅 するまで培養を続けた. 細胞がほとんど死滅した時点で $10 \%$ の牛 胎仔血清を含んだ DMEM 培地に戻し, 生育した細胞を血清飢餓 耐性株とし，2E 3-bcl 2-LS（LS：Low Serumの意）と命名し た.

抗体濃度の測定 抗体濃度の測定は, ELISA 法 (Engvall et $a l ., 1971)$ によった. 定量の標準検体としては, $2 \mathrm{E} 3$ 細胞の培養 上清から精製した抗体を用いた。

$b c l-2$ タンパク発現量の定量 $\quad b c l-2$ タンパク量の定量は, ELISA 法 (Engvall et al., 1971) によった。一次抗体としてウサ ギ由来抗 $b c l-2$ 抗体 (Calbiochem), 二次抗体としてマウス由来

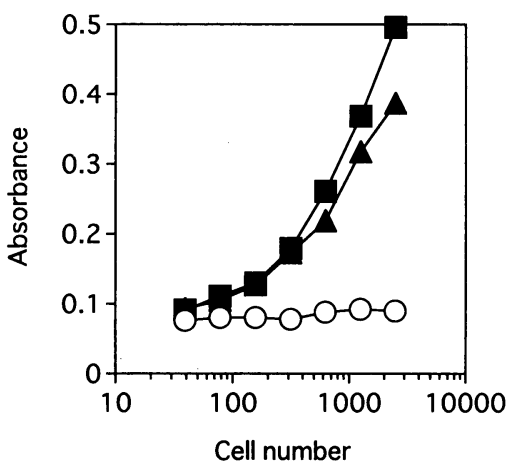

Absorbance of wild type cell lysate (O), 2 E 3-bcl 2 cell lysate $(\boldsymbol{\Delta})$, and $2 \mathrm{E} 3-b c l$ 2-LS cell lysate

Fig. 2 Quantification of $\mathrm{Bcl}-2$ protein expression

抗 $b c l-2$ 抗体 (Boehringer Mannheim), 三次抗体として西洋わ さびペロキシダーゼ（Bio Source International）で標識したヤギ 由来抗マウス IgG 抗体, を用いた。

\section{2. 実験結果と考察}

\section{$2.12 \mathrm{E} 3-b c l$ 2-LS 株の樹立}

$2 \mathrm{E} 3-b c l 2$ を $0.2 \%$ の FBS を含んだ DMEM 培地で 8 日間培 養し,この時点での細胞の生存率（生細胞密度 $\div$ 総細胞密度）は $2.1 \%$ であった。この血清飢餓環境を経験した細胞を通常の $10 \%$ の FBS を含んだ DMEM 培地に戻して培養した。この後 12 日間 ほどは, 顕微鏡観察によると, 細胞が分裂して双球の状態になっ ていても，その一方が死滅している場合が多く，血清飢餓にさら したことで細胞が正常な増殖能を喪失しているのではないかと思 われた. 3 週間の継代培養の後, 細胞分裂が回復した。細胞増殖が 血清飢餓にさらされる前と同程度であることを確認してからここ

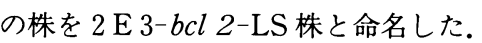

\section{2 血清飢餓状態での細胞生存率の変遷}

$b c l-2$ 遺伝子を導入した $2 \mathrm{E} 3-b c l 2$ 細胞, さらにこれを血清飢

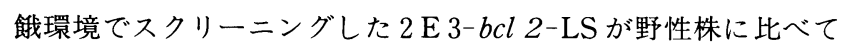
どの程度の細胞死耐性が付与されたかを検討した。各々 150,000 cells $/ m l$ の初期細胞密度で, $0.2 \%$ FBS 含 DMEM 培地で培養し た. 培養は 24 ウェルプレート（岩城硝子）を用い, トリプリケイ トで行った。

Fig. 1(a)に, 総細胞密度 (生細胞密度と死細胞密度の和) の時 間変遷を示す. 全培養期間を通じて, 総細胞数がほぼ一定で, 細 胞の増殖がほとんど停止していた。この時の細胞生存率（生細胞 密度（総細胞密度)を Fig. 1(b)に示す. 培養 2 日目の細胞生存率 は, 野性株が $30 \pm 3 \%, 2$ E 3-bcl 2 株が 70 $16 \%, 2$ E 3-bcl 2-LS 株が $93 \pm 4 \%$ であった。培養期間についてみてみると，野性株の 場合，培盖一日目には細胞生存率が $80 \%$ を下回ったが，一方，2 E 3-bcl 2 株の場合, 細胞生存率が $90 \%$ を下回るのは培養 2 日目

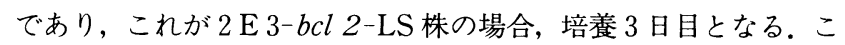

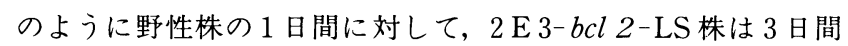
と, 血清飢餓環境での培養期間が 3 倍伸びていた。

\section{$2.3 B c l-2$ タンパク発現量の測定}

血清飢餓状態での細胞死耐性が Bcl-2 タンパク発現量と相関 があるかを検討するために, 細胞数をそろえて作成した細胞破砕 液中の Bcl-2 タンパク発現量を ELISA 法で測定した。この時の 検体はすべて, 通常の $10 \% \mathrm{FBS}$ を含んだ培地中で対数増殖期に ある細胞から調製した。その結果を Fig. 2 に示す.野性株には Bcl -2 タンパクの発現は見られない.一方で, 2 E 3-bcl 2-LS 株は 2 


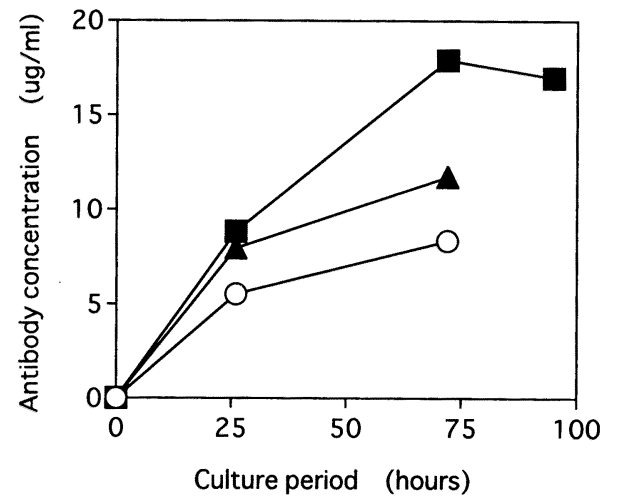

Wild type (O), 2 E 3-bcl 2 ( $\mathbf{\Delta})$, 2 E 3-bcl 2-LS

Fig. 3 Time course of antibody concentration in culture supernatant

E 3-bcl 2 株よりも高い $\mathrm{Bcl}-2$ 発現が見られる. その程度を次の ように解析した. $2 \mathrm{E} 3-b c l$ 2-LS 株から調製した検体の吸光度は 同一細胞数の $2 \mathrm{E} \mathrm{3-bcl} 2$ のものより高いが 2 倍の細胞数の $2 \mathrm{E} 3$

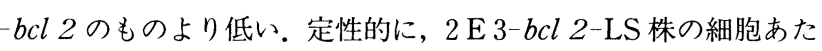
り Bcl-2 発現量は, $2 \mathrm{E} 3-b c l$ のそれより高いが 2 倍未満である といえる. 実際, $2 \mathrm{E} 3-b c l$ 2 から調製した検体を内部標準として

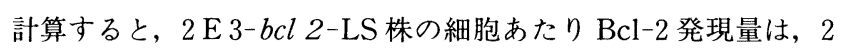
E 3-bcl 2 のそれの 1.4 倍であった. すなわち, 血清飢餓の経験が 細胞あたり $\mathrm{Bcl}-2$ タンパク発現量の高い細胞の選択につながっ

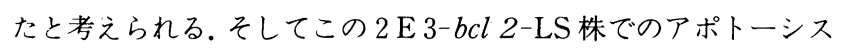
抑制因子 Bcl-2 タンパク発現立進が, 血清飢餓環境での培養期間 延長の一因であると思われる.

\section{4 血清飢餓環境での抗体生産}

Fig. 1 の培養での, 培養上清中の抗体濃度の測定結果を Fig. 3 に示す.培養 3 日目の時点で比較すると, 培養上清中の抗体濃度は 野性株で $8.3 \pm 0.7 \mu \mathrm{g} / \mathrm{m} l, 2 \mathrm{E} 3-b c l$ 2株で $11.8 \pm 1.1 \mu \mathrm{g} / \mathrm{ml}, 2$ E 3-bcl 2-LS 株で $17.9 \pm 1.7 \mu \mathrm{g} / \mathrm{ml}$ であった. すなわち, 同一培

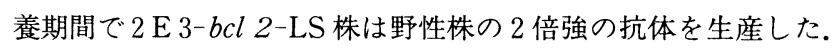
しかし培養 3 日目, 4 日目の $2 \mathrm{E} 3-b c l$ 2-LS 株の生存率がそれぞ れ $66 \pm 6 \%, 25 \pm 3 \%$ であったにも関わらず, 培養 3 日目から 4 日 目には新たな抗体生産は認められなかった. すなわち, 細胞の死 滅に先立って, 有用タンパク生産が停止した. 今回の血清飢餓培 養は, 初期細胞密度が $150,000 \mathrm{cells} / \mathrm{ml}$ であり, 培養期間での生 細胞数を時間で積分した生細胞積分は 700,000 cells・daysにすぎ ず, 通常の血清濃度で培養した場合はその 4 倍以上の $3,000,000$ cells·days 前後であることから, たとえばグルコースやアミノ酸 といった培地中の低分子の栄養物質がまだ十分に培地中に残存し, アンモニアや乳酸などの有害老廃物の蓄積もそれほどでは無いと 考えられる。すなわち血清濃度が極度に低いことを除けば培養環 境はまだまだタンパク質生産が行いうる状態であると推測される ので, な抢細胞にタンパク生産を行わせるよう改良の余地がある と思われる.これは, 血清飢餓環境における有用物質生産を考之 る場合, 解決されるべき課題である.

培養 3 日目までの比抗体生産速度を, Fig. 1 と Fig. 3 を用いて 計算で求めた。すなうち, 生細胞数を培養時間で積分して生細胞 数時間を求めた。抗体生産量を生細胞数時間で割り, 比抗体生産 速度を算出した. その結果と, 別に求めた野性株の $10 \%$ FBS 含培 地での対数增殖期の比抗体生産速度を Fig. 4 に示す.これまでの 培養の経験から野性株の $10 \% \mathrm{FBS}$ 含培地での対数増殖期の比抗 体生産速度は, 7 15 pg/cell/day 程度で, Fig. 4 では 9.8 pg/cell/

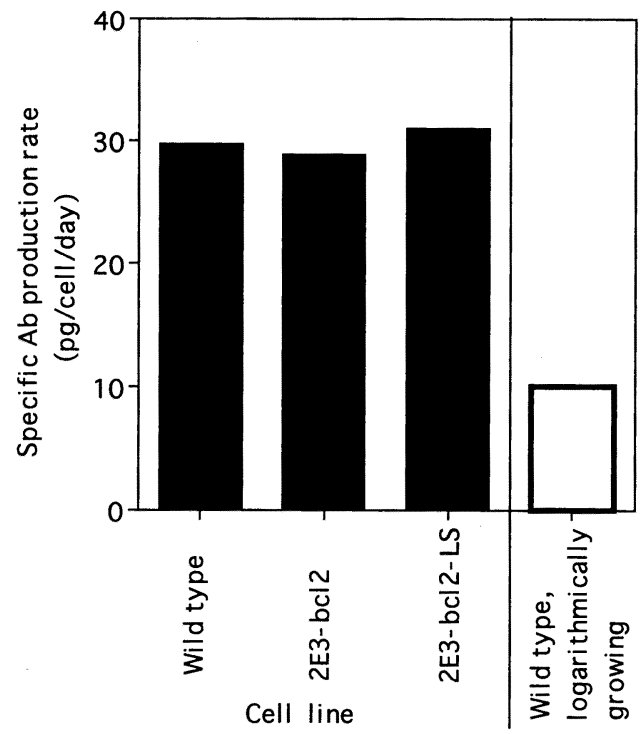

Fig. 4 Specific antibody production rate The specific antibody production rate was calculated using cell density, cell viability and antibody concentration data between 0 and 72 hours of culture time shown in Fig. 1 and Fig. 3.

day の場合を示した. 血清飢餓状態での比抗体生産速度は野性株, 2E 3-bcl 2 株, 2E 3-bcl 2-LS 株がそれぞれ $29.8 \mathrm{pg} / \mathrm{cell} / \mathrm{day}$, $28.9 \mathrm{pg} / \mathrm{cell} / \mathrm{day}, 31.1 \mathrm{pg} / \mathrm{cell} / \mathrm{day}$ とほぼ同じ值を示し, 対数増 殖期の 3 倍程度であった.これは, 血清飢餓によって増殖が抑制さ れ, 細胞が細胞周期中の比抗体生産速度の高い $\mathrm{G}_{1}$ 期に集中した ためではないかと推測される.

\section{3. 結}

細胞增殖の抑制によって細胞周期が抗体生産に有利な $\mathrm{G}_{1}$ 期に 停止し, これによる比抗体生産速度の向上, モノクローナル抗体 の精製に要するコストの削減, の二つが期待される血清飢䬻培養 の実現を目指して, ハイブリドーマ細胞にアポトーシス抑制遺伝 子 $b c l-2$ を導入し, さらにこれを血清飢䬻環境でスクリーニング して 2 E 3-bcl 2-LS 株を樹立した.

（1） 2E 3-bcl 2-LS 株は野性株に比べて血清飢餓に強い耐 性を示し, 2 日程度長く培養ができた。

(2) 2 E 3-bcl 2 よりも 2E 3-bcl 2-LS 株の方が Bcl-2 タン パクを 1.4 倍発現していた。 これが培養期間の長期化の一因と推 測される。

（3）培養の長期化により, 抗体の生産量は野性株の 2 倍強ま で高められた。

（4）血清飢餓状態の細胞は予想通り対数増殖期の細胞に比べ て 3 倍程度高い比抗体生産速度を示した。

[謝 辞] 本研究の遂行に当たって, 名古屋大学の上平正道先生には 大変有益なご助言を頂きました。また, 本研究は文部省科学研究費補助金 （特別研究員獎励費）によってなされました. また寺田聡は学術振興会の特 別研究員 (PD) として本研究に従事しました. ここに深く感謝の意を表し ます。

\section{Literature cited}

Engvall, E. and P. Perlman; "Enzyme-Linked Immunosorbent Assay (ELISA). Quantitative Assay of Immunoglobulin G," Immunochemistry, 8, 871-874 (1971) 
Garatun-Tjeldst $\phi$, O., I. F. Pryme, J. K. Weltman and R. M. Dowben ; "Synthesis and Secretion of Light-Chain Immunoglobulin in Two Successive Cycles of Synchronized Plasmacytoma Cells," J. Cell Biol., 68, 232-239 (1976)

Itoh, Y., H. Ueda and E. Suzuki ; “Overexpression of bcl-2, Apoptosis Suppressing Gene: Prolonged Viable Culture Period of Hybridoma and Enhanced Antibody Production," Biotechnology and Bioengineering, 48, 118-112 (1995)

Karasuyama, H., A. Kudo, and F. Melchers ; "The Proteins Encoded by the VpreB and Lambda 5 pre-B Cell-Specific Genes can Associate with Each Other and with Mu Heavy Chain," J. Exp. Med., 172, 969 -972 (1990)

Mikami, T., F. Makishima and E. Suzuki ; "Enhancing Effect of Mouse Peritoneal Exudate Cells and their Products on Antibody Productivity of Hybridoma Cells : application of in vivo factors to in vitro culture," Cytotechnolgy, 7, 93-101 (1991)

Murakami, H., T. Shinomura, T. Nakamura, H. Ohashi, K. Shiohara and H. Omura ; "Development of a Basal Medium for Serum-Free Cultivation of Hybridoma Cells in High Density," Nippon Nogeikagaku Kaishi, 58, 575-583 (1984)

Ogawa, T., M. Kamihira, S. Terashima, K. Yasuda, S. Iijima and T. Kobayashi; "High cell Density Cultivation of Anchorage-Dependent Cells Using a Novel Macroporus Cellulosic support," J. Ferment. Bioeng., 74, 27-31 (1992)

Omasa, T., K. Higashiyama, S. Shioya and K. Suga; "Effects of Lactate-Controlled Fed-Batch Operation,” Biotechnol. Bioeng., 39, 556-564 (1992)
Shirai, Y., M. Yamaguchi, A. Kobayashi, A. Nishi, H. Nakamura and H. Murakami ; "Change in Growth Kinetics of Hybridoma Cells Entrapped in Collagen Gel Affected by Alkaline Supply," Cytotechnolgy, 14, 129-146 (1994)

Suzuki, E., K. Takahashi, F. Makishima and H. Morita; "Enhanced Antibody Productivity of Hybridomas due to Growth-Suppression - Experimental and theoretical search for optimal growth-suppression methods -," Kagaku Kogaku Ronbunshu, 19, 198-205 (1993)

Terada, S., H. Takamatsu, H. Morita, F. Makishima and E. Suzuki ; "Molecular Biological Analysis of Perfusion Culture of Hybridoma and Effective Production of Monoclonal Antibody using Interleukin-6," Kagaku Kogaku Ronbunshu, 19, 206-212 (1993)

Terada, S., T. Fujita, K. Fukuoka, T. Komatsu and E. Suzuki ; "Proliferation Control of Hybridoma Cells, Avoiding Cell Death by Expression of Apoptosis Suppressing Genes," Chemical Engineering Symposium Series 57, Tone, S., M. Taya, S. Takamatsu and T. Masawaki eds., p. 140-144, The Society of Chemical Engineers, Japan (1997)

Tsujimoto, Y.; "Stress-Resistance Conferred by High Level of bcl-2 Alpha Protein in Human B lymphoblastoid Cell," Oncogene, 4, 1331 -1336 (1989)

Yamamoto, S., M. Katsui, X-H Xing and H. Unno ; "Morphological Change of Recombinant CHO Cell Andits Relation to G-CSF Productivity," Chemical Engineering Symposium Series 57, Tone, S., M. Taya, S. Takamatsu and T. Masawaki eds., p. 145-148, The Society of Chemical Engineers, Japan (1997)

\title{
Establishing an Apoptosis-Resistant Hybridoma Cell Line for Usage in Serum Starvation Culture
}

\section{SATOSHI TERADA ${ }^{1}$, YOHITO ITOH ${ }^{1}$ and EIJI SUZUKI ${ }^{2}$}

\author{
${ }^{1}$ Department of Chemistry and Biotechnology, Graduate School of Engineering, the University of Tokyo, \\ Tokyo 113 \\ ${ }^{2}$ Catalysis Science Lab., Research Institute of Innovative Technology for the Earth, Soraku-gun, Kyoto 619 \\ $-02$
}

Key words: hybridoma, monoclonal antibody, apoptosis, $b c l-2$, serum starvation.

A serum starvation culture of hybridoma cells is desirable because serum starvation stops cell cycling at the $\mathrm{G}_{1}$ phase, where hybridoma cells produce more antibody in the other phases, However, serum starvation induces apoptosis, a type of cell death, forcing the culture to die out. In this research, the authors aimed at inhibition of cell death during serum starvation culture. A hybridoma cell line $b c l$ -2 was transfected with $b c l-2$, an apoptosis suppressing gene, and named $2 \mathrm{E} 3-b c l 2$. Then the cells were screened in serum starvation culture to obtain $2 \mathrm{E} 3-b c l$ 2-LS. The expression level of Bcl-2 protein in $2 \mathrm{E} 3-b c l$ 2-LS was higher by $40 \%$ than that in $2 \mathrm{E} 3-b c l$ 2. In serum starvation culture, $2 \mathrm{E} 3$ - $b c l$ 2-LS survived longer by two days and produced twice as much antibody as the wild type. 